\title{
Hjertekirurgiregisteret og fagmiljøene
}

\author{
Norsk thoraxkirurgisk forening etablerte i 1994 et landsdekkende register for all hjertekirurgi i Norge. \\ Registeret inneholder opplysninger om operasjonstyper, risikofaktorer, komplikasjoner og 30-dagers leta- \\ litet. I denne kronikken diskuterer vi våre erfaringer med registeret og betydningen av eierskap, definisjoner, \\ et begrenset antall variabler som registreres og betydningen av gode tilbakemeldinger til fagmiljøene.
}

\author{
Jan L. Svennevig \\ j.l.svennevig@medisin.uio.no \\ Thoraxkirurgisk avdeling \\ Hjerte-lungeklinikken \\ Oslo universitetssykehus \\ Rikshospitalet \\ 0407 Oslo

\section{Leidulf Segadal} \\ Thoraxkirurgisk seksjon \\ Hjerteavdelingen \\ Haukeland universitetssykehus

\section{Rune Haaverstad} \\ Thoraxkirurgisk seksjon \\ Hjerteavdelingen \\ Haukeland universitetssykehus \\ og \\ Norsk thoraxkirurgisk forening
}

Norsk thoraxkirurgisk forening vedtok i 1992 å etablere et landsdekkende register for all hjertekirurgi i Norge. Foreningens kvalitets- og datautvalg er styringsgruppe for registeret. Statutter ble vedtatt i 1993. Definisjoner av variabler som registreres, er basert på databasen til den amerikanske Society of Thoracic Surgery (1) og internasjonal konsensus om hvordan resultater skal rapporteres (2). Dette gjør det mulig å sammenlikne norske resultater med resultater fra utenlandske registre. Databasen, som eies av foreningen, inneholder opplysninger om over 60000 kirurgiske inngrep på hjertet og de store, hjertenære kar. Styret er ansvarlig for at basen forvaltes i henhold til vedtektene. Registeret samarbeider med Norsk Cardiologisk Selskap, og det lages årlig en felles publikasjon om åpen kirurgi og intervensjonsbehandling av koronarpasienter i Norge (3). Det norske hjertekirurgiregisteret var blant de første til å rapportere data til det europeiske hjertekirurgiregisteret. Begge registre er fleksible med henblikk på valg av registreringsverktøy og kan konvertere alle vanlige dataformater. Det europeiske hjertekirurgiregisteret har foreløpig gitt ut fire publikasjoner (4). Norsk thoraxkirurgisk forening dekker nødvendige utgifter til sekretærhjelp, kontorutstyr og fagmøter. Det øvrige arbeidet har vært honorært, ulønnet tillitsmannsarbeid.
Foreningen har tidligere mottatt tilskudd fra Helsetilsynet, men i de siste årene kun fra Legeforeningens kvalitetssikringsfond.

Registeret viser de betydelige endringene som har funnet sted i løpet av registreringsperioden, 1994-2008 (5). Koronarkirurgi er fortsatt den hyppigst utførte typen inngrep, ca. 3000 operasjoner årlig (fig 1). Størst økning er det for aortaklaffekirurgi og operasjoner på torakalaorta. Det opereres flere eldre pasienter og flere nyfødte. Det er uforklarlig store forskjeller mellom fylkene med hensyn til antall opererte per 100000 pasienter (fig 2). Relativt mange pasienter opereres i de nordligste fylkene. Røykevaner, tungt arbeid og kaldt klima er mulige forklaringer på dette, men databasen kan ikke bidra til å forklare de store forskjellene.

Resultatene tåler sammenlikning med de beste resultater fra utenlandske registre. Operasjonsletaliteten (30-dagers dødelighet) for det hyppigste inngrepet, som er koronar bypasskirurgi, ligger så lavt som $1,5 \%$. Også for klaffekirurgi er resultatene gode til tross for den store andelen eldre pasienter. Det har vært en jevn reduksjon i mortaliteten for barnehjertekirurgi, på linje med det vi har sett i Sverige (6).

\section{Eierskap}

Vi har sju store offentlige medisinske registre i Norge. Disse er hjemlet i helseregisterloven av 18.5. 2001. Hvert av disse registrene har sin egen forskrift. Dertil kommer ca. 50 medisinske kvalitetsregistre (7). Vårt register har, på linje med en rekke andre medisinske kvalitetsregistre, utgangspunkt i kvalitetsarbeid i regi av Den norske legeforening. Statens helsetilsyn har funnet det tvilsomt om spesialforeningene i Legeforeningen kan stå som juridisk eier av et register (8). Av de ca. 50 medisinske kvalitetsregistrene innenfor den somatiske spesialisthelsetjenesten som er omtalt i Sosialog helsedirektoratets rapport fra mars 2004 (9), er 36 så omfattende at direktoratet mener de kan betegnes som nasjonale registre. Arbeidsgruppen bak rapporten anbefaler at 15 av registrene, inklusive hjertekirurgiregisteret, oppgraderes til nasjonale medisinske kvalitetsregistre, og at det lages felles elektroniske løsninger for tilbakemelding til avdelingene som rapporterer, sammenstilling av data og publisering. Videre anbefaler arbeidsgruppen at regionale helseforetak skal være databehandlingsansvarlige for hver sine nasjonale registre, og dermed ha et overordnet ansvar for faglig tilrettelegging og forvaltning/teknisk drift.

Vi mener at Legeforeningens spesialforeninger fortsatt bør kunne eie og drive medisinske kvalitetsdatabaser. Offentlige medisinske registre baserer seg på diagnose- og behandlingskoder som registreres når pasienten skrives ut (10). Vi mener det er vanskelig å basere registrering av risikofaktorer og komplikasjoner på ICD- og prosedyrekoder alene. Tradisjonelt har de medisinske kvalitetsregistrene hentet inn data ved bruk av registreringsskjema eller ved innsending av en datafil. Enkelte databaser har nå tatt i bruk web-basert onlineregistrering (11). Det er vist at medisinske kvalitetsregistre kan føre til forbedret kvalitet på behandlingen (12), og registerdata kan brukes til helseforskning og politiske avgjørelser. Vår type register kan være sårbart fordi det forutsetter lokal kompetanse, entusiasme og villighet til frivillig og ubetalt registreringsarbeid. Dette gjelder ikke bare for sekretariatsfunksjonene, men også for det arbeidet som legges ned ved hvert hjertekirurgisk senter. Vi tror likevel at eierskapet til et register er av stor betydning for kvaliteten. Vi opplever en stor grad av lojalitet overfor registeret med hensyn til kompletthet og datakvalitet og frykter at datakvaliteten vil reduseres hvis man blir pålagt å registrere for et regionalt helseforetak. Ekstern kontroll av data (audit) ville vært ønskelig, men ville kreve ressurser utover det Norsk thoraxkirurgisk forening i dag kan tilby. Vi tror at en slik kvalitetssikring av data best kan utføres av spesialforeningens kvalitetssikringsutvalg og finansieres av Legeforeningen.

\section{Rapportering og publisering}

Alle sentrene får tilsendt oversikt over egne data og resultater, samt en landsoversikt. Samletall for hele landet offentliggjøres 


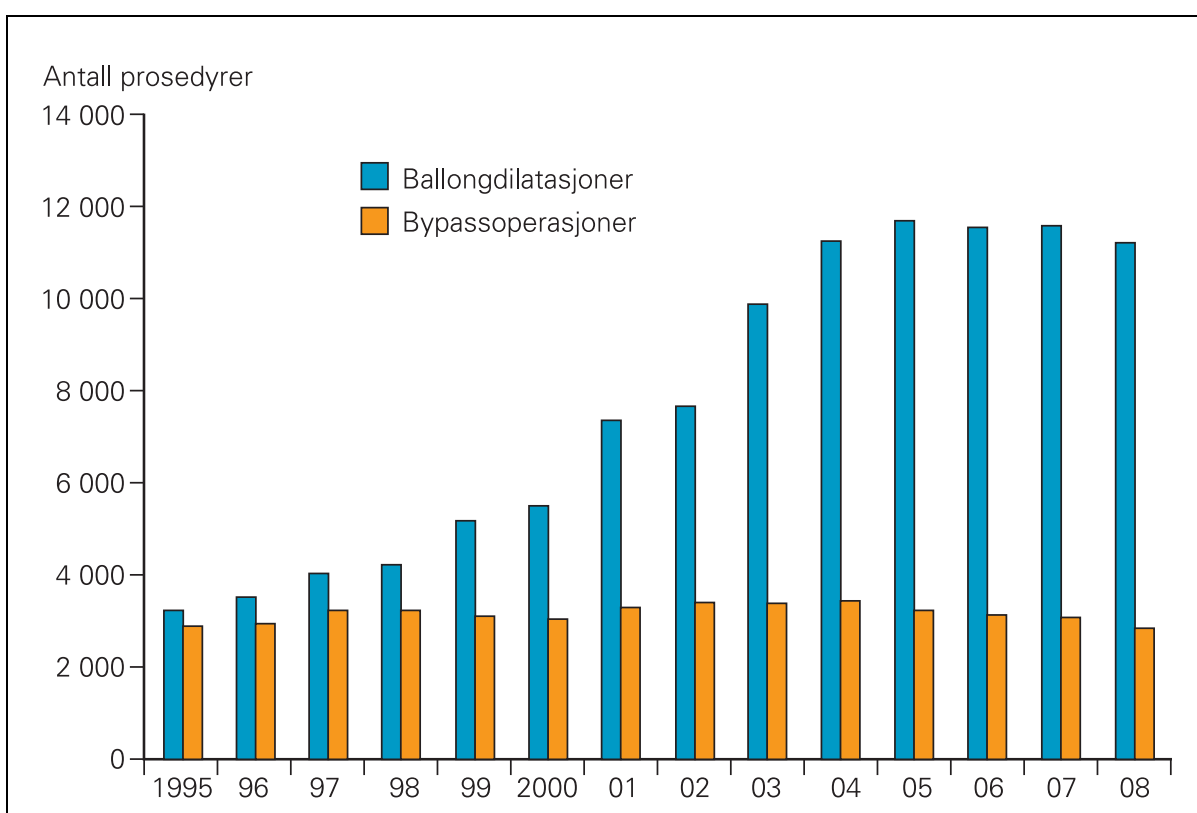

Figur 1 Utviklingen i koronarkirurgi og ballongdilatasjon (PCI) 1995-2008 på sykehusenes eller Legeforeningens hjemmesider (5). Skjema for Sentralregisteret er vist på www.tidsskriftet.no/ svennevigappendiks. Databasen er avidentifisert. Datatilsynet har ikke gitt tillatelse til at pasientidentitet registreres, med mindre hver pasient gir informert samtykke. Slikt samtykke vil ikke være mulig fordi en stor andel av pasientene legges inn med redusert bevissthet (kardiogent sjokk, hypovolemisk sjokk ved ruptur av aneurismer etc). Betydelige forskjeller i pasientprofil, type inn- grep og liggetid mellom sykehusene gjør det vanskelig å sammenlikne resultater (for eksempel operasjonsletalitet og postoperative komplikasjoner) mellom sykehus. Data fra hjertekirurgiregisteret viser at opptil halvparten av de pasientene som dør innen 30 dager etter et inngrep, dør etter utskrivning fra egen avdeling. Det er derfor viktig at de enkelte sykehus ikke bare registrerer dødsfall i sykehus. Det finnes metoder for å måle pasienttyngde innen hjertekirurgi. I Norge har alle sju avdelin- gene tatt i bruk Euroscore, et skåringssystem som antyder forventet risiko forbundet med en hjerteoperasjon (13), basert på risikofaktorer og type inngrep.

Så langt har ikke alle sykehus sagt seg villig til å publisere egne resultater, selv om tiden synes moden for slik rapportering (14). At registeret ikke er pasientidentifiserbart fratar oss muligheten for langtids overlevelsesstudier. En omfattende større analyse av medisinske kvalitetsregistre viser at få registre inkluderer kostnader ved behandling (15). Vårt register gir heller ikke mulighet for å beregne kostnader knyttet til de enkelte prosedyrer. Sammenliknet med det europeiske registeret og den amerikanske STS-databasen er resultatene for norsk hjertekirurgi gode. Norske hjerteopererte er imidlertid ikke eldre og på ingen måte sykere enn pasientene i SentralEuropa. Antall kvinner som opereres er lavt. Andelen pasienter med fedme og diabetes mellitus er også lav (7). Andelen pasienter som opereres akutt er som forventet. Operasjonsletaliteten har ikke økt til tross for at pasientene blir eldre og i noen grad også tyngre. Det kan tyde på at kvaliteten på hjertekirurgien i Norge stadig blir bedre.

\section{Konklusjon}

Det norske hjertekirurgiregistret går inn i sitt 15. år. Alle sju avdelinger rapporterer samtlige inngrep. Registerdata presenteres på Legeforeningens hjemmeside og på hjemmesiden til de enkelte sykehusene. Legeforeningens medlemmer kan fritt klippe og lime fra denne presentasjonen og NTKF opplever en økende interesse for de årlige rapportene. Registeret har nå funnet en endelig form og det er ingen planer om større endringer eller utvidelser.

\section{Appendiks www.tidsskriftet.no/ svennevigappendiks}

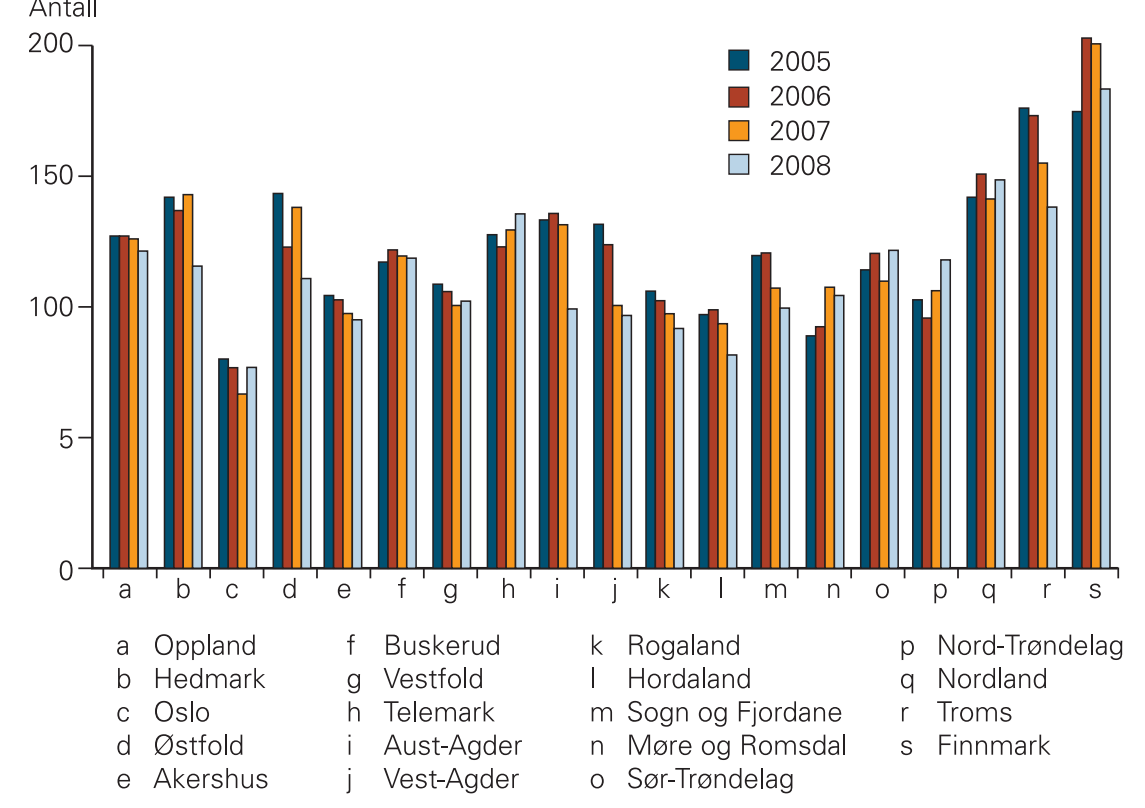

Figur 2 Fylkesfordeling for alle hjerteoperasjoner
Oppgitte interessekonflikter: Rune Haaverstad har $i$ åtte år vært leder av Norsk thoraxkirurgisk forening lfagmedisinsk forening i Den norske legeforeningl som eier Norsk nasjonalt hjertekirurgiregister

\section{Litteratur}

1. Clark RE. The Society of Thoracic surgeons National Database status report. Ann Thorac Surg 1994; 57: $20-6$.

2. Edmunds LH jr., Clark RE, Cohn LH et al. Guidelines for reporting morbidity and mortality after cardiac valvular operations. The American Association for Thoracic Surgery. Ad Hoc Liaison Committee for Standardizing Definitions of Prosthetic Heart Valve Morbidity. Ann Thorac Surg 1996; 62: 932-5.

3. Melberg T, Svennevig JL. Hjertekirurgisk- og koronar intervensjonsstatistikk 2008. Hjerteforum 2010; 23: 9-14.

4. Bridgewater B, Gummert J, Walton PKH et al. Towards global benchmarking: The Fourth EACTS Adult Cardiac Surgical Database Report 2010. Henley-on-Thames, Oxfordshire, UK: Dendrite Clinical Systems, 2010.

5. Hjertekirurgiregisteret. www.legeforeningen.no/ id/84429.0 (21.10.2010). 
6. Berggren $\mathrm{H}$, Olin C. Svensk kongenital hjärtkirurgi. Från djärva pionjärinsatser till operationsresultat i världklass. Läkartidningen 2005; 102: 2309-14.

7. Cappelen I, Lyshol H. Oversikt over helseregistre i Norge. Nor Epidemiol 2004: 14: 33-8.

8. Nasjonale kvalitetsregistre. Rammeverk for etablering og drift. Oslo: Statens helsetilsyn, 2001.

9. Norske kvalitetsregistre - forslag til eierskap og drift. Rapport fra Sosial-og helsedirektoratet til Helsedepartementet. Oslo: Sosial- og helsedirektoratet, 2004

10. Gummert JF, Funkat A, Beckmann A et al. Cardiac surgery in Germany during 2007: a report on behalf of the German Society for Thoracic and Cardiovascular Surgery. Thorac Cardiovasc Surg 2008; 56: 328-36.

11. Motomura N, Miyata H, Tsukihara H et al. Risk model of thoracic aortic surgery in 4707 cases from a nationwide single-race population through a web-based data entry system: the first report of 30 -day and 30-day operative outcome risk models for thoracic aortic surgery. Circulation 2008; 118 (14 suppl): $153-9$.

12. Cameron PA, Gabbe BJ, Cooper DJ et al. A statewide system of trauma care in Victoria: effect on patient survival. Med J Aust 2008; 189: 546-50.

13. Roques F, Nashef FSA, Michel $P$ et al. Risk factors and outcome in European cardiac surgery: analysis of the EuroSCORE multinational database of 19030 patients. Eur J Cardiothorac Surg 1999; 15: 816-22.

14. Svennevig JL. Åpenhet om operasjonsresultater. Tidsskr Nor Legeforen 1999: 20: 119.

15. Raftery J, Roderick P. Stevens A. Potential use of routine databases in health technology assessment. Health Technol Assess 2005: 9: 1-92.

Mottatt 17.12. 2009, første revisjon innsendt 20.4. 2010, godkjent 21.10. 2010. Medisinsk redaktør Lars Inge Frich. 